\title{
Kelengkapan Pengisian Formulir Laporan Operasi Kasus Bedah Obgyn Sebagai Alat Bukti Hukum
}

\author{
Listia Nur Febrianti' ${ }^{1}$ Ida Sugiarti ${ }^{2}$ \\ 1,2Poltekkes Kemenkes Tasikmalaya, Jl. Cilolohan No. 35 Kota Tasikmalaya \\ llistianurfebrianti@gmail.com²ida.sugiarti@dosen.poltekkestasikmalaya.ac.id
}

\begin{abstract}
According to the Ministry of Health Decree No. 129 of 2008 concerning Minimum Standards Services in Hospitals, filling medical record include surgery report forms must be 100\% that can be used as legal evidence. Preliminary study addressing 10surgery report form of obgyn surgery cases in December 2017 wasn't filled complete. Knowing how the implementation filling of the surgery report formof obgyn surgery cases as a legal evidence in RSUD Ciamis District Ciamis in quarter IV 2017.Methods: Descriptive with mixed method approach, a total sample is 82 surgery report forms, and the research informant is a obgyn surgeon, coordinator of administration and medical record service, and surgical nurse.The average percentage of completeness surgery report forms of the general surgery cases in the IV quarter of 2017 was 63,78\%. Inhibitory factors are limited time, patient quantity, delay in medical record control, too much items filled of form. Average percentage of surgery report form filling still below the Minimum Standards Services. Hospital shouldimprove the causal factors that inhibit the incompleteness of surgery report form.
\end{abstract}

Keywords: Filling form, surgery report, legal evedience, obgyn surgery

\begin{abstract}
Abstrak
Pengisian dokumen rekam medis harus 100\%menurut Keputusan Menteri Kesehatan No. 129 Tahun 2008 tentang Standar Minimal Pelayanan di Rumah Sakit,termasuk formulir laporan operasi yang dapat berfungsi sebagai alat bukti hukum. Hasil studi pendahuluan menujukan 10 formulir laporan operasi kasus bedah obgyn bulan Desember 2017 tidak terisi secara lengkap.Tujuan penelitian untuk mengetahui bagaimana pengisian formulir laporan operasi kasus bedah obgyn sebagai alat bukti hukum di RSUD Ciamis Kabupaten Ciamistriwulan IV tahun 2017. Metodologi Penelitian deskriptif dengan pendekatan mixed methode, total sample 82 formulir laporan operasi, dan informan penelitian adalah dokter bedah obgyn, koordinator administrasi dan pelayanan rekam medis, serta perawat bedah. Hasil Penelitian menunjukkan rata-rata persentase kelengkapan pengisian laporan operasi kasus bedah obgyn adalah $63,78 \%$. Faktor penghambat ketidak lengkapan adalah keterbatasan waktu, jumlah pasien, keterlambatan pengembalian dokumen rekam medis, tidak ada pelaporan ketidaklengkapan pengisian laporan operasi, dan item yang harus diisi banyak. Rata-rata presentase kelengkapan pengisian laporan operasi masih di bawah standar pelayanan minimal. Sebaiknya Rumah Sakit memperbaiki faktor penyebab yang menghambat tidak terisinya laporan operasi.
\end{abstract}

Kata Kunci : Pengisian formulir, laporan operasi, alat bukti hukum, bedah obgyn

\section{Pendahuluan}

Pelayanan kesehatan dengan pasien membentuk suatu hubungan yakni hubungan medis dan hubungan hukum dalam bidang pemeliharaan kesehatan (Purwohadiwaryo dalam Astuti, 2009). Hubungan hukum yang terjadi antara dokter dan pasien berdasarkan pada ikhtiar berupa pelayanan kesehatan yang optimal dengan adanya bukti diantaranya: 1) adanya informed consent (IC), 2) sesuai dengan prosedur, 3) sesuai dengan tugas pokok dan fungsi, dan 4) terdokumentasi di dalam rekam medis (Sugiarti, 2017). Rekam medis dalam pengisiannya dituntut untuk terisi secara lengkap, karena erat kaitannya dengan fungsi keuangan yakni dalam proses pengklaiman serta fungsi hukum yakni sebagai alat bukti hukum. Rekam medis dapat dijadikan sebagai petunjuk dalam pembuktian berupa tulisan atau dokumen apabila terjadi sengketa atau perkara.Hal tersebut dikarenakan rekam medis mempunyai posisi sentral dalam pelayanan medis baik untuk kepentingan tugas 
profesi maupun kepentingan pasien terutama bila adanya kemungkinan jika terjadi konflik hukum di pengadilan.

Peran rekam medis salah satunya adalah sebagai aspek hukum, artinya suatu berkas rekam medis sebagai bukti telah terjadinya proses pelayanan kesehatan. Rekam medis memiliki peran penting dalam hukum pembuktian, termasuk formulir formulir yang terdapat di dalam rekam medis yang mempunyai fungsi dan makna tertentu dalam setiap itemnya. Salah satunya yaitu laporan operasi yang merupakan produk rekam medis yang bersifat kekal atau diabadikan, (Hatta, 2013). Surat Edaran Dirjen Pelayanan Medik Tahun 1995 Nomor HK.00.06.1.5.01160 tentang Petunjuk Teknis Pengadaan Formulir Rekam Medis dan Pemusnahan Arsip Rekam Medis di Rumah sakit menjelaskan bahwa laporan operasi merupakan salah satu lembar rekam medis yang dipilah atau tidak dimusnahkan (Budi, 2011). Laporan operasi merupakan laporan atau catatan mengenai prosedur pembedahan terhadap pasien (Hatta, 2013).

Laporan operasi merupakan salah satu formulir rekam medis yang akan dijadikan sebagai alat bukti, oleh karena itu berdasarkan Permenkes Nomor 269 tahun 2008 tentang Rekam Medis pasal 2 dinyatakan bahwa rekam medis harus dibuat secara tertulis, lengkap dan jelas. Secara hukum, dokumen rekam medis yang tidak diisi dengan lengkap, tidak memenuhi aspek hukum dan lemah sebagai alat bukti, dikarenakan menurut Keputusan Menteri Kesehatan Nomor 129 Tahun 2008 tentang Standar Minimal Pelayanan di Rumah Sakit, pengisian dokumen rekam medis harus $100 \%$. Hal tersebut berarti bahwa setiap formulir di dalam rekam medis harus diisi secara lengkap. Bila catatan dan data terisi lengkap, maka rekam medis akan menolong semua yang terlibat. Sebaliknya, bila catatan yang ada hanya sekedarnya saja, apalagi kosong pasti akan merugikan dokter dan rumah sakit(Hanafiah dan Amir,1999).

Penelitian yang dilakukan oleh Hidayat (2012) tentang tinjauan terhadap kelengkapan pengisian laporan tindakan operasi di Rumah Sakit Pelni Petamburan menunjukkan 90 formulir laporan operasi 80 diantaranya tidak terisi secara lengkap, yang berarti hanya 10 formulir yang diisi secara lengkap. Dari 20 variabel, hanya 3 variabel yang diisi secara lengkap yaitu nama pasien, operator dan patologi anatomi (Hidayat, 2012). Sedangkan berdasarkan hasil studi pendahuluan dengan cara observasi formulir laporan operasi pada dokumen rekam medis di RSUD Ciamis Kabupaten Ciamis, terdapat tiga tenaga medis yang tidak mengisi secara lengkap formulir laporan operasi, mulai dari nama hingga bukti autentikasi yaitu nama dokter yang bertanggungjawab, terutama pada kasus obgyn yang merupakan tindakan invasif dengan jumlah terbanyak yang memerlukan formulir laporan operasi sebagai bukti prosedur tindakan operasi yang dilakukan terhadap pasien. Rekapitulasi jumlah pelayanan invasif yang memerlukan formulir laporan operasi pada tahun 2017adalah kasus obgyn 1543 pasien, bedah umum 868 pasien, dan bedah orthopedi 414 pasien. Salah satu kasus tertinggi bedah obgyn tahun 2017 terdapat pada triwulan IV yakni sebanyak 448 kasus dibandingkan dengan jumlah kasus pada triwulan lainnya. Hasil studi pendahuluan menunjukan seluruh formulir laporan operasi dari 10 dokumen rekam medis kasus bedah obgyn bulan Desember tahun 2017 tidak terisi secara lengkap, yaitu total persentase kelengkapan pengisian adalah $63,5 \%$ dengan rincian 146 kolom yang tidak terisi. Item yang paling banyak tidak terisi adalah mengenai jaringan yang dieksisi.

\section{Metode}

Jenis penelitian ini adalah deskriptif, dengan pendekatan kuantitatif dan kualitatif (mixed method) dengan strategi eksplanatoris sekuensial (sequential explanatory) yakni melakukan penelitian kuantitatif pada tahap pertama dan penelitian kualitatif pada tahap kedua. Penelitian kuantitatif dilakukan dengan observasi pada formulir laporan operasi kasus bedah obgyn, kemudian dilakukan wawancara in depth interview untuk memperdalam penelitian. Hasil data observasi dan wawancara akan di analisis bersamaan untuk mendapatkan jawaban atas rumusan masalah pada penelitian ini.

Populasi dalam penelitian ini adalah seluruh formulir laporan operasi kasus obgyn Triwulan IV tahun 2017 yaitu sebanyak 448 dokumen rekam medis. Subjek PenelitianInforman penelitian adalah 2 orang perawat bedah di ruang Operative Kamer (OK), koordinator administrasi dan pelayanan rekam medis, dan dokter bedah obgyn yang melakukan tindakan operasi.Sampel penelitian adalah 82 formulir laporan operasi kasus bedah obgyn pada triwulan IV tahun 2017. 
Teknik pengambilan sampel yang digunakan dalam penelitian ini adalah teknik pengambilan sampel menggunakan metode probability sampling dengan teknik random sampling.Pada penelitian kualitatif pemilihan subjek penelitian menggunakan metode non probability sampling dengan jenis snowball sampling. Informan untuk penelitian kualitatif menggunakan informan yang terdiri dari dokter bedah obgyn sebagai informan pertama (I1), petugas rekam medis bagian analising sebagai informan kedua (I2) dan ketiga perawat bedah di ruang OK sebagai informan ketiga dan keempat (I3 dan I4).

Teknik analisis data kuantitatif yang akan dilakukan pada penelitian ini adalah dengan cara menghitung persentase kelengkapan pengisian formulir laporan operasi dan informed consent. Teknik analisis data kualitatif adalah dengan cara analisis hasil wawancara secara tematik. Tahap selanjutnya, membandingkan data hasil penelitian kuantitatif pada tahap pertama, dan data hasil penelitian kualitatif tahap kedua.

\section{Hasil Penelitian}

Kelengkapan Pengisian Formulir Laporan Operasi Kasus Bedah Obgyn sebagai Alat Bukti Hukum

Hasil analisis formulir laporan operasikasus bedah obgyn pada triwulan IV dengan jumlah sampel 82 dokumen rekam medisyang dilaksanakan oleh penulis adalah sebagai berikut:

Hasil Analisis Berdasarkan Bulan pada Triwulan IV tahun 2017

Tabel 1. Hasil Analisis Kelengkapan Formulir Laporan Operasi Kasus Bedah Obgyn Periode Triwulan IV Tahun 2017di RSUD Ciamis Kabupaten Ciamis

\begin{tabular}{cccccc}
\hline No & Bulan & $\begin{array}{c}\text { Jumlah } \\
\text { Dokumen }\end{array}$ & $\begin{array}{c}\text { Leng- } \\
\text { kap }\end{array}$ & $\begin{array}{c}\text { Tidak } \\
\text { Leng- } \\
\text { kap }\end{array}$ & $\begin{array}{c}\text { Rata- } \\
\text { rata } \\
\text { Peng- } \\
\text { isian }\end{array}$ \\
\hline 1 & Oktober & 27 & 0 & 27 & $64,07 \%$ \\
\hline 2 & November & 28 & 0 & 28 & $68,04 \%$ \\
\hline 3 & Desember & 27 & 0 & 27 & $59,07 \%$ \\
\hline & Jumlah & 82 & 0 & 82 & $63,78 \%$ \\
\hline
\end{tabular}

Berdasarkan hasil penelitian yang dilakukan oleh penulis, diketahui bahwa dari 82 formulir laporan operasi pada triwulan IV tahun 2017, keseluruhan formulir laporan operasi tidak terisi secara lengkap dengan rata - rata pengisian sebesar $63,78 \%$ dengan rincian pengisian laporan operasi per item adalah sebagai berikut :

Tabel 2. Hasil Analisis Kelengkapan Formulir Per Item Laporan Operasi Kasus Bedah Obgyn Periode Triwulan IV Tahun 2017 di RSUD Ciamis Kabupaten Ciamis

\begin{tabular}{|c|c|c|c|c|c|}
\hline \multirow{2}{*}{\multicolumn{2}{|c|}{$\begin{array}{l}\text { Analisis Keleng- } \\
\text { kapan Form }\end{array}$}} & \multicolumn{2}{|c|}{ Pengisian } & \multirow{2}{*}{$\begin{array}{l}\text { Jum- } \\
\text { lah }\end{array}$} & \multirow{2}{*}{$\begin{array}{l}\text { Persen- } \\
\text { tase }\end{array}$} \\
\hline & & Ya & Tidak & & \\
\hline 1 & $\begin{array}{l}\text { Teknik } \\
\text { Operasi } \\
\text { \&Temuan } \\
\text { Intra Operasi }\end{array}$ & 82 & 0 & 82 & $100.00 \%$ \\
\hline 2 & Ahli Anestesi & 79 & 3 & 82 & $96.30 \%$ \\
\hline 3 & $\begin{array}{l}\text { Jam operasi } \\
\text { selesai }\end{array}$ & 78 & 4 & 82 & $95.15 \%$ \\
\hline 4 & Asisten I & 77 & 5 & 82 & $93.92 \%$ \\
\hline 5 & $\begin{array}{l}\text { Jam operasi } \\
\text { dimulai }\end{array}$ & 77 & 5 & 82 & $93.92 \%$ \\
\hline 6 & $\begin{array}{l}\text { Ttd Dokter/ } \\
\text { Nakes }\end{array}$ & 77 & 5 & 82 & $93.83 \%$ \\
\hline 7 & Pembedah & 76 & 6 & 82 & $92.72 \%$ \\
\hline 8 & $\begin{array}{l}\text { Indikasi } \\
\text { Operasi }\end{array}$ & 75 & 7 & 82 & $91.40 \%$ \\
\hline 9 & Jenis Operasi & 75 & 7 & 82 & $91.40 \%$ \\
\hline 10 & $\begin{array}{l}\text { Pernyataan } \\
\text { Persetujuan }\end{array}$ & 74 & 8 & 82 & $90.17 \%$ \\
\hline 11 & $\begin{array}{l}\text { Jenis } \\
\text { Anestesi }\end{array}$ & 70 & 12 & 82 & $85.27 \%$ \\
\hline 12 & $\begin{array}{l}\text { Nama } \\
\text { Operator/ } \\
\text { Dokter }\end{array}$ & 65 & 17 & 82 & $79.06 \%$ \\
\hline 13 & SMF & 63 & 19 & 82 & $76.72 \%$ \\
\hline 14 & $\begin{array}{l}\text { Pemberi } \\
\text { Informasi }\end{array}$ & 61 & 21 & 82 & $74.47 \%$ \\
\hline 15 & $\begin{array}{l}\text { Perawat } \\
\text { Instrumen }\end{array}$ & 60 & 22 & 82 & $72.97 \%$ \\
\hline 16 & Asisten II & 60 & 22 & 82 & $72.93 \%$ \\
\hline 17 & $\begin{array}{l}\text { Informasi } \\
\text { yang } \\
\text { diberikan }\end{array}$ & 59 & 23 & 82 & $72.13 \%$ \\
\hline 18 & Titi mangsa & 56 & 26 & 82 & $68.03 \%$ \\
\hline 19 & $\begin{array}{l}\text { Komplikasi } \\
\text { Intra Operasi }\end{array}$ & 55 & 27 & 82 & $66.93 \%$ \\
\hline
\end{tabular}




\begin{tabular}{|c|c|c|c|c|c|}
\hline \multirow{2}{*}{\multicolumn{2}{|c|}{$\begin{array}{l}\text { Analisis Keleng- } \\
\text { kapan Form }\end{array}$}} & \multicolumn{2}{|c|}{ Pengisian } & \multirow{3}{*}{$\begin{array}{c}\begin{array}{c}\text { Jum- } \\
\text { lah }\end{array} \\
82\end{array}$} & \multirow{3}{*}{$\begin{array}{c}\begin{array}{c}\text { Persen- } \\
\text { tase }\end{array} \\
66.89 \%\end{array}$} \\
\hline & & \multirow{2}{*}{$\begin{array}{l}\text { Ya } \\
55\end{array}$} & \multirow{2}{*}{$\begin{array}{c}\text { Tidak } \\
27\end{array}$} & & \\
\hline 20 & $\begin{array}{l}\text { Desinfeksi } \\
\text { Kulit dengan }\end{array}$ & & & & \\
\hline 21 & $\begin{array}{l}\text { Dikirim ke } \\
\text { bagian PA }\end{array}$ & 54 & 28 & 82 & $65.70 \%$ \\
\hline 22 & $\begin{array}{l}\text { Penerima } \\
\text { Informasi }\end{array}$ & 53 & 29 & 82 & $64.81 \%$ \\
\hline 23 & $\begin{array}{l}\text { Jaringan yang } \\
\text { dieksisi }\end{array}$ & 51 & 31 & 82 & $61.99 \%$ \\
\hline 24 & $\begin{array}{l}\text { Yg dikirim } \\
\text { ke bagian } \\
\text { lab utk } \\
\text { pemeriksaan } \\
\text { (bila ada) }\end{array}$ & 50 & 32 & 82 & $60.76 \%$ \\
\hline 25 & Nama & 49 & 33 & 82 & $59.92 \%$ \\
\hline 26 & $\begin{array}{l}\text { Penjabaran } \\
\text { Komplikasi } \\
\text { Intra Operasi }\end{array}$ & 48 & 34 & 82 & $58.29 \%$ \\
\hline 27 & $\begin{array}{l}\text { Lama } \\
\text { Operasi } \\
\text { Berlangsung }\end{array}$ & 46 & 36 & 82 & $55.69 \%$ \\
\hline 28 & $\begin{array}{l}\text { Diagnosa } \\
\text { Pra-Bedah }\end{array}$ & 41 & 41 & 82 & $50.53 \%$ \\
\hline 29 & $\begin{array}{l}\text { Instruksi } \\
\text { Pasca Bedah }\end{array}$ & 40 & 42 & 82 & $48.50 \%$ \\
\hline 30 & $\begin{array}{l}\text { Diagnosa } \\
\text { Pasca-Bedah }\end{array}$ & 37 & 45 & 82 & $45.55 \%$ \\
\hline 31 & $\begin{array}{l}\text { Operasi Akut/ } \\
\text { Terencana }\end{array}$ & 37 & 45 & 82 & $44.58 \%$ \\
\hline 32 & $\begin{array}{l}\text { Ruang } \\
\text { Operasi }\end{array}$ & 36 & 46 & 82 & $43.47 \%$ \\
\hline 33 & $\mathrm{JK}$ & 33 & 49 & 82 & $40.39 \%$ \\
\hline 34 & Kamar & 29 & 53 & 82 & $35.10 \%$ \\
\hline 35 & Ruangan & 28 & 54 & 82 & $34.13 \%$ \\
\hline 36 & No RM & 27 & 55 & 82 & $33.25 \%$ \\
\hline 37 & $\begin{array}{l}\text { Tanggal } \\
\text { Lahir }\end{array}$ & 26 & 56 & 82 & $31.70 \%$ \\
\hline 38 & $\begin{array}{l}\text { Posisi } \\
\text { Penderita }\end{array}$ & 14 & 68 & 82 & $17.20 \%$ \\
\hline 39 & $\begin{array}{l}\text { Macam } \\
\text { Sayatan }\end{array}$ & 11 & 71 & 82 & $13.49 \%$ \\
\hline 40 & Pendarahan & 8 & 74 & 82 & $9.88 \%$ \\
\hline & $\begin{array}{l}\text { a - rata } \\
\text { engkapan }\end{array}$ & 2092 & 1188 & 3280 & $63.78 \%$ \\
\hline
\end{tabular}

Berdasarkan tabel 2 diketahui bahwa item pada formulir laporan operasi dengan angka kelengkapan terendah adalah item pendarahan $(9,88 \%)$, macam sayatan $(13,49 \%)$, posisi penderita $(17,20 \%)$, dan tanggal lahir $(31,70 \%)$ sehingga menyebabkan formulir laporan operasi tidak terisi secara lengkap.

\section{Faktor Penghambat Pelaksanaan Pengisian For-} mulir Laporan Operasi

Berdasarkan hasil wawancara yang dilakukan oleh penulis pada empat informan (karakteristik informan terlampir) menunjukan terdapat 5 tema sebagai faktor penghambat pelaksanaan pengisian formulir laporan operasi, adapun faktor-faktor yang menghambat pelaksanaan pengisian formulir laporan operasi kasus bedah obgyn di RSUD Ciamis Kabupaten Ciamis pada periode triwulan IV tahun 2017 adalah sebagai berikut:
a. Tema I: Keterbatasan Waktu
b. Tema II: Jumlah Pasien
c. Tema IV : Keterlambatan Pengembalian Dokumen Rekam Medis
d. Tema IV : tidak ada pelaporan kelengkapan pengisian laporan operasi
e. Tema VI : Item yang harus diisi banyak

\section{Pembahasan}

Persentase Kelengkapan Pengisian Laporan
Operasi Kasus Bedah Obgyn sebagai Alat Bukti
Hukum di RSUD Ciamis Triwulan IV tahun 2017

Berdasarkan hasil penelitian dapat diketahui bahwa rata-rata kelengkapan formulir laporan operasi kasus bedah obgyn periode Triwulan IV tahun 2017 di RSUD Ciamis Kabupaten Ciamis adalah 64\%, hasil analisis tersebut menunjukan bahwa angka kelengkapan tersebut kurang dari standar pelayanan minimal rumah sakit, karena standar minimal pengisian dokumen rekam medis termasuk formulir - formulir yang ada di dalamnya, salah satunya yaitu laporan operasimenurut Peraturan Mentri Kesehatan nomor 129 Tahun 2008 tentang Standar Pelayanan Minimal adalah 100\%, yang berarti bahwa setiap kolom dalam formulir tersebut harus diisi secara lengkap dan menyeluruh. Berdasarkan SPO dan hasil wawancara kepada petugas di ruang Operative Kamer (OK), diketahui bahwa pengisian formulir laporan operasi dilakukan oleh dua petugas yang berbeda, yakni dokter dan perawat. Perawat mengisi item bagian identitas diantaranya SMF (Staf Medik Fungsional), nomor rekam medis, nama, jenis kelamin, tanggal lahir, ruangan, ruang operasi, akut/terencana, kamar, dan pukul. Sedangkan, untuk dokter mengisi item lain selain 
yang diisi oleh perawat. Mulai dari pembedah hingga autentikasi (nama dan tanda tangan dokter). Adapun pembahasan dari setiap item pengisian formulir laporan operasi berdasarkan petugas yang mengisi adalah sebagai berikut :

\section{Formulir Laporan Operasi yang Diisi oleh Per- awat}

Identitas merupakan salah satu aspek kelengkapan pengisian laporan operasi mengenai data demografi yang berisi informasi yang berhubungan dengan pasien. Item-item yang terdapat pada bagian identitas di dalam formulir laporan operasi dapat dijadikan sebagai alat bukti hukum. Identitas di dalam formulir laporan operasi ini dapat digunakan sebagai petunjuk mengenai kepemilikian formulir sehingga dapat menjadi acuan ketika laporan operasi diminta sebagai alat bukti hukum yakni berdasarkan identitas lengkap pasien atau pihak yang terkait (nama, alamat, umur, dan sebagainya) dalam kasus medikolegal. Identitas pasien pada formulir laporan operasi terdiri dari nomor rekam medis, nama, jenis kelamin, dan tanggal lahir. Namun, terdapat beberapa tambahan item mengenai informasi pasien sebelum prosedur pembedahan, diantaranya SMF, ruangan (ruang rawat inap), ruang operasi, operasi akut/terencana dan kamar (kamar operasi).

Hasil penelitian yang dilakukan oleh penulis menujukan bahwa pengisian item identitas pada formulir laporan operasi tidak terisi secara lengkap, terutama item tanggal lahir dengan persentase kelengkapan sebesar $31,70 \%$ yang berarti bahwa dari 82 formulir hanya 26 formulir yang item tanggal lahirnya diisi. Dengan demikian, angka tersebut masih dibawah standar pengisian minimal, yang mewajibkan dokumen rekam medis termasuk setiap formulir di dalamnya terisi secara lengkap. Berdasarkan hasil wawancara, ketidaklengkapan pengisian item - item pada bagian identitas pasien terjadi karena petugas sibuk mempersiapkan banyak hal sebelum melakukan operasi serta banyaknya formulir yang harus diisi, sehingga beberapa kolom lupa terisi. Menurut Sudra (2013) dijelaskan bahwa setiap dokumen rekam medis wajib mencantumkan identitas, hal ini untuk menghindari kendala apabila formulir terlepas dari folder, sehingga mudah untuk digabungkan kembali dalam satu folder. Formulir yang terlepas dari folder dan di dalamnya tidak mencantumkan identitas yang lengkap, maka akan sulit untuk dikembalikan ke foldernya sehingga dapat menyebabkan salah satu alat bukti hukum hilang. Setiap point dalam identitas pasien sangatlah penting, karena berisi informasi yang hanya dimiliki oleh pasien tersebut. Apabila item identitas hanya terdiri dari nama saja, hal tersebut tidak dapat memberikan informasi yang akurat mengenai siapa pemilik dari formulir tersebut, karena di dalam satu rumah sakit terdapat kemungkinan adanya nama yang sama dengan jenis kelamin sama.Salah satu fungsi dokumen rekam medis khususnya laporan operasi adalah sebagai alat bukti hukum baik alat bukti tertulis, alat bukti surat, dan keterangan ahli. Hal ini sesuai dengan hasil penelitian Rahayu dan Sugiarsi(2014) Dilihat dari fungsinya bahwa nama pasien harus selalu ada pada setiap lembar formulir untuk mencegah apabila ada salah satu formulir lepas dari dokumen rekam medis maka petugas lebih mudah menggabungkan kembali, untuk menghindari tertukarnya dokumen rekam medis antara pasien satu dengan pasien yang lain dan penulisan nama harus dilakukan dengan benar.

\section{Formulir Laporan Operasi yang Diisi oleh Dokter}

Pembuatan laporan operasi dilakukan oleh dokter penanggung jawab pasien (DPJP) yang sering disebut sebagai operator dimulai dari pengisian diagnosa pre operasi hingga bukti autentikasi berupa tanda tangan dan nama dokter (operator). Hasil penelitian yang dilakukan oleh penulis menunjukan bahwa terdapat item yang belum terisi lengkap, yakni item pendarahan dengan persentase kelengkapan sebesar $9,88 \%$, yang berarti bahwa dari 82 formulir hanya 8 formulir yang diisi, sedangkan item lain yang memeiliki kelengkapan rendah diantaranya item macam sayatan $(13,49 \%)$ dan posisi penderita $(17,20 \%)$.

Laporan operasi berisi informasi mengenai diagnosa pre dan pasca operasi; deskripsi tentang prosedur pembedahan; deskripsi tentang seluruh temuan normal dan tidak normal; deskripsi tentang kejadian unik dan tidak lazim dalam pembedahan; deskripsi tentang spesimen yang diambil; nama ahli bedah (operator) dan asisten yang membantu; tanggal dan lama proses pembedahan. Item - item tersebut harus diisi secara lengkap, karena dapat menghasilkan informasi mengenai hal-hal yang dilakukan pada saat pelaksanaan tindakan operasi, terutama yang berkaitan dengan kesesuaian dan ketidaksesuaian prosedur tindakan yang telah dilakukan (Hatta, 2013).

Isi dari laporan operasi yang dapat dikategorikan sebagai catatan yang penting adalah satu-satunya aspek yang hanya bisa diisi oleh dokter, sedangkan perawat tidak memiliki kewenangan dalam 
pengisian catatan penting tersebut, sehingga dokter bertanggung jawab penuh dalam pengisian aspek tersebut. Hal tersebut dikarenakan praktisi yang melakukan tindakan operasi pada pasien dan bertanggung jawab penuh atas segala sesuatu yang terjadi pada saat proses operasi adalah seorang dokter yang sering disebut sebagai operator. Aspek catatan penting harus diisi secara lengkap, karena salah satunya berkaitan dengan pendokumentasian pelayanan yang dilakukan kepada pasien, yaitu dapat menjadi bukti bahwa dokter telah melakukan tindakan operasi sesuai dengan prosedur.

Laporan operasi tentunya membutuhkan informed consent sebagai salah satu bukti adanya transaksi teurapeutik atau pernyataan persetujuan antara dokter dan pasien sebelum dilakukannya suatu tindakan terutama untuk tindakan invasif yang memiliki resiko tinggi. Hal tersebut diatur dalam Permenkes nomor 290 tahun 2008 tentang Persetujuan Tindakan Kedokteran, pasal 3 ayat (1) yang menyatakan :

"Setiap tindakan kedokteran yang mengandung resiko tinggi harus memperoleh persetujuan tertulis yang ditandatangani oleh yang berhak memberikan persetujuan"

Identitas dan isi laporan operasi merupakan hal yang penting, namun autentikasi juga merupakan hal yang harus diperhatikan. Kelengkapan pengisian aspek autentikasi di RSUD Ciamis Kabupaten Ciamis dapat dikatakan cukup baik, karena untuk item tanda tangan dokter memiliki rata-rata pengisian sebesar $93,65 \%$, persetujuan tindakan $90,13 \%$ dan nama operator/dokter $78,93 \%$. Namun, hal tersebut masih belum dapat dikatakan lengkap karena seharusnya terisi secara lengkap. Peraturan Menteri Kesehatan Nomor 269 tahun 2008 tentang Rekam Medis Pasal 5 ayat (4) menjelaskan :

"Setiap pencatatan ke dalam rekam medis harus dibubuhi nama, waktu, dan tanda tangan dokter, dokter gigi atau tenaga kesehatan tertentu yang memberikann pelayanan kesehatan secara langsung"

Pengisian autentikasi dapat digunakan untuk mengetahui siapa yang bertanggung jawab terhadap perawatan yang diberikan kepada pasien. Autentikasi yang dibutuhkan selain dari pihak dokter sebagai penanggung jawab adalah atutentikasi pada formulir informed consent, yang juga memerlukan autentikasi dari pihak keluarga atau pasien sendiri sebagai tanda persetujuan atas tindakan kedokteran yang akan di terima oleh pasien terkait.

\section{Faktor Penghambat Pelaksanaan Pengisian Formulir Laporan Operasi}

Berdasarkan hasil wawancara yang dilakukan oleh penulis, terdapat 5 faktor penghambat yang membuat formulir laporan operasi tidak dapat terisi secara lengkap, adapun pembahasan dari setiap faktornya adalah sebagai berikut :

\section{Keterbatasan Waktu}

Faktor ini dianggap menjadi faktor penghambat yang paling utama dari ketidaklengkapan pengisian laporan operasi dimana informan menyatakan perbandingan yang tidak sebanding antara jam kerja dokter, waktu yang tersedia dan jumlah pasien yang harus dilayaninya. Meskipun tidak ada hukum yang mengikat mengenai jam kerja dokter, merujuk pada pasal 77 ayat (2) Undang - undang Nomor 13 tahun 2003 tentang Ketenagakerjaan yang mengatur bahwa waktu kerja maksimum seorang tenaga kerja adalah tujuh jam satu hari (untuk lima hari kerja per minggu). Namun, kenyataannya dokter seringkali bekerja lebih lama dari aturan tersebut. Hal tersebut terjadi karena di Indonesia, terdapat regulasi bahwa dokter yang telah memiliki Surat Izin Praktik (SIP) dapat bekerja di tiga tempat sebagaimana tertuang dalam Peraturan Menteri Kesehatan Nomor 512 tahun 2007 tentang Izin Praktik dan Pelaksanaan Praktik Kedokteran. Regulasi tersebut mengakibatkan jam kerja dokter tinggi dan menjadikan dokter harus berpindah tempat ke pelayanan kesehatan lainnya dalam kurun waktu tertentu.

\section{Jumlah Pasien}

Jumlah pasien juga menjadi salah satu faktor yang menghambat pelaksanaan pengisian laporan operasi, meskipun jumlah pasien menjadi hal yang relatif karena jumlahnya yang tidak pasti.Namun, di saat pasien yang harus ditangani segera ada pada jumlah yang banyak, maka kewajiban seorang dokter adalah untuk menanganinya segera namun tetap sesuai dengan prosedur, sehingga dapat mempengaruhi waktu yang tersedia untuk pengisian laporan operasi. Berdasarkan hasil wawancara, dinyatakan bahwa untuk tindakan operasi dengan kasus operasi besar contohnya sectio cesarea (SC) membutuhkan waktu minimal 30 menit, namun untuk kasus operasi besar dengan komplikasi dapat membutuhkan waktu hingga 3 jam. Hal tersebut berarti bahwa jumlah pasien dapat melipatgandakan beban kerja dokter sehingga dapat mengurangi waktu yang harus digunakan untuk pengisian laporan operasi 
yang mengakibatkan laporan operasi diisi secara tergesa - gesa dan tidak terisi secara lengkap yang mengakibatkan laporan operasi tidak memenuhi asas legalitas atau tidak sah secara hukum.

\section{Keterlambatan Pengembalian Dokumen Rekam Medis}

Salah satu hal yang dapat menghambat dalam pengisian formulir laporan operasi adalah keterlambatan pengembalian dokumen rekam medis dari ruang rawat pasien, sehingga proses analisis kelengkapandan pengembalian ke ruang rawat inap untuk dilengkapi pun terhambat. Idealnya, dokumen rekam medis dikembalikan 1×24 jam setelah pasien pulang, namun dalam pelaksanaannya tidak sesuai dengan standar (Sudra, 2011). Pada saat proses pengembalian dokumen rekam medis ke bangsal/ ruangan terkait, unit rekam medis tidak memberikan lembar ceklis kepada petugas, sehingga petugas tidak melengkapi bagian yang harus dilengkapi dengan alasan tidak tahu apa yang harus dilengkapi.

\section{Tidak Ada Pelaporan Kelengkapan Pengisian Laporan Operasi}

Tidak dibuatnya laporan mengenai hasil analisis kuantitatif pengisian formulir rekam medis khususnya laporan operasi menyebabkan para petugas yang mengisi laporan operasi tidak mengetahui persentase atau tingkat kelengkapan pengisian laporan operasi, sehingga tidak ada bahan untuk dilakukan evaluasi mengenai kelengkapan pengisian.Hal tersebut mengakibatkan tidak adanya tindak lanjut sebagai upaya dalam meningkatkan kelengkapan pengisian formulir laporan operasi.

Tidak dibuatnya laporan hasil analisis kuantitatif juga tidak sesuai dengan salah satu kompetensi perekam medis dan informasi kesehatan yang tercantum dalam Surat Keputusan DPP PORMIKI Nomor 08/PORMIKI/XI/2016 tentang Standar Kompetesi Perekam Medis dan Informasi Kesehatan (PMIK) pada standar Pemanfaatan Ilmu Statistik Kesehatan untuk Riset salah satunya yaitu mengelola kualitas dan peningkatan kinerja. Berkaitan dengan salah satu standar akreditasi rumah sakit yakni di dalam kelompok standar manajemen rumah sakit pada bagian Manajemen Informasi Rekam Medis (MIRM), pada standar MIRM 13.4 terdiri dari beberapa elemen penilaian diantaranya dilakukan review yang berfokus pada ketepatan waktu, keterbacaan dan kelengkapan rekam medis, kemudian hasil review dilaporkan secara berkala (Standar Nasional
Akreditasi Rumah Sakit, 2018). Dalam penelitian Daryanti dan Sugiarsi(2016) dijelaskan bahwa penyebab tidak terisinya laporan penting terutama pada lembar informed consent adalah kurang kerja sama antara dokter penanggung jawab dengan perawat pendamping untuk menuliskan informasi, antara lain diagnosis dan tata cara tindakan medis, tujuan tindakan medis yang dilakukan, alternatif tindakan lain.

Perekam medis dalam melaksanakan tugasnya, diwajibkan untuk melakukan analisis dan mengembalikan setiap dokumen yang tidak lengkap untuk dilengkapi kepada petugas yang terkait.Namun, di RSUD Ciamis, petugas hanya menganalisis melalui lembar ceklis tanpa dibuat laporan kemudian mengembalikannya ke ruangan, sedangkan dokumen yang dikembalikan tetap tidak terisi secara lengkap (dokumen bandel) dan tidak ada tindak lanjut untuk menanganinya.

\section{Item yang Harus Diisi Banyak}

Formulir laporan operasi merupakan salah satu hal yang mempengaruhi kelengkapan pengisian laporan operasi, baik dari segi desain formulir maupun item atau konten yang harus diisi. Menurut Hatta (2013), laporan operasi berisi informasi mengenai diagnosa pre dan pasca operasi; deskripsi tentang prosedur pembedahan; deskripsi tentang seluruh temuan normal dan tidak normal; deskripsi tentang kejadian unik dan tidak lazim dalam pembedahan; deskripsi tentang spesimen yang diambil; nama ahli bedah (operator) dan asisten yang membantu; tanggal dan lama proses pembedahan. Namun, item tersebut dipengaruhi oleh kebutuhan dari masing - masing rumah sakit itu sendiri, sehingga terdapat beberapa item yang ditambahkan sesuai dengan kebutuhan.Formulir laporan operasi di RSUD Ciamis Kabupaten Ciamis khusus bagian obgyn terdiri dari 36 item yang harus diisi. Item item tersebut bila dibandingkan dengan item yang dikemukakan oleh Gemala Hata, jumlah item ini terbilang banyak. Berdasarkan hasil wawancara dengan 4 praktisi di rumah sakit yang bertugas mengisi laporan operasi, mengatakan bahwa item yang harus diisi dari laporan operasi terbilang cukup banyak, namun disesuaikan dengan kebutuhan akan informasi dari laporan operasi yang dapat menunjang seluruh proses pemberian tindakan koperasi kepada pasien. Salah satunya terdapat pengulangan item formulir pada formulir satu dengan yang lainnya. Berdasarkan hasil wawancara dengan informan I, 
item posisi penderita dan macam sayatan terdapat pada formulir bagian anestesi, sehingga untuk pengisian terkadang tidak dilakukan karena sudah diisi oleh petugas lain pada formulir lain. Sedangkan, untuk item pendarahan yang merupakan kelengkapan terendah disebabkan karena dokter bedah mengisi tidak pada kolom item pendarahan, namun diisi pada item teknik dan temuan intra operasi sehingga menjadikan petugas tidak menyadari adanya data mengenai pendarahan. Item tanggal lahir juga, yang merupakan salah satu bagian dari identitas dengan angka kelengkapannya rendah terjadi karena petugas perawat harus mengisi beberapa formulir yang harus diisi sebelum melakukan tindakan operasi serta melakukan persiapan untuk proses operasi, sehingga pengisiannya menjadi tergesa- gesa bahkan hingga tidak diisi. Oleh karena itu, dibutuhkan review atau analisis mengenai desain formulir dari laporan operasi untuk mengetahui item yang harus disediakan dan yang harus diperbaiki, salah satunya pada saat evaluasi bersama komite medik. Mendesain formulir merupakan salah satu standar kompetensi profesi rekam medis sesuai dengan Surat Keputusan DPP PORMIKI Nomor 08/PORMIKI/XI/2016 tentang Standar Kompetesi Perekam Medis dan Informasi Kesehatan (PMIK) pada standar Manajemen Data Kesehatan yakni mengelola isi, struktur dan data kesehatan. Desain formulir tentunya harus didesain berdasarkan kebutuhan dari setiap praktisi yang akan melakukan pengisian pada formulir dan standar item yang harus dipenuhi guna menghasilkan informasi yang dibutuhkan bagi pelayanan maupun dalam pembuktian hukum.

\section{Simpulan}

Pelaksanaan kegiatan pengisian laporan operasi sebagai alat bukti hukum di RSUD Ciamis Kabupaten Ciamis belum memenuhi standar pelayanan minimal rumah sakit, sehingga tidak dapat optimal digunakan sebagai alat bukti hukum bila terjadi tuntutan hukum, yang dapat merugikan tenaga kesehatan.

\section{Daftar Pustaka}

Astuti, Endang Kusuma. (2009). Transaksi Terapeutik dalam Upaya Pelayanan Medis di Rumah Sakit. Bandung: Citra Aditya Bakti.

Barama, Michael. (2011). Kedudukan Visum Et Repertum dalam Hukum Pembuktian. [Online].
Tersedia : http://repo.unsrat.ac.id/69/1/ KEDUDUKAN_VISUM_ET_REPERTUM DALAM_HUKUM_PEMBUKTIAN.pdf. [2 $\overline{6}$ Januari 2018]

Buamona, Hasrul. (2016). Medical Record and Informed Consent sebagai Alat Bukti dalam Hukum Pembuktian. Yogyakarta : Parama Publishing.

Budi, Savitri Citra. (2011). Manajemen Unit Kerja Rekam Medis. Yogyakarta : Quantum Sinergis Media.

Cook, John., Sankaran, Balu., \& Wasunna, Ambrose E.O. (1991). Surgery At The Distric Hospital : Obstetrics, Gynaecology, Orthopaedics, and Traumatology. WHO.

Daryanti, Sugiarsi S. (2016). Analisis Kelengkapan Pengisian Formulir Persetujuan Tindakan Kedokteran Kasus Bedah Mayor di RSUD Ambarawa. Jurnal Rekam Medis. Vol.10 No.1

Eleanora, Fransiska Novita. (2013). Analisis Yuridis Rekam Medis sebagai Alat Bukti Surat. Dalam Forum Ilmiah [Online]. Volume 10 Nomor 3. Tersedia:http://ejurnal.esaunggul. ac.id/index.php/formil/article/view/891. [24 Januari 2018]

Guwandi, J. (2004). Informed Consent. Jakarta : Balai Penerbit FKUI.

. (2005). Rahasia Medis. Jakarta : Balai Penerbit FKUI.

Hanafiah, M. Jusuf dan Amir, Amri. (1999). Etika Kedokteran dan Hukum Kesehatan (Edisi 3). Jakarta : Buku Kedokteran EGC.

Haryanto, Eko Yudhi. (2015). Kedudukan Rekam Medis Dalam Pembuktian Perkara Malpraktek Di Bidang Kedokteran. DalamLex Crimen [Online]. Volume IV nomor 2. Tersedia: http:// media.neliti.com/media/publications/3254ID-kedudukan-rekam-medis-dalampembuktian-perkara-malpraktek-di-bidangkedokteran.pdf. [26 Januari 2018].

Hatta, Gemala R. (2013). Pedoman Manajemen Informasi Kesehatan di Sarana Pelayanan Kesehatan (Edisi Revisi 2) .Jakarta : Universitas Indonesia.

Hidayat, Sony. (2012). Tinjauan Terhadap Kelengkapan Pengisian Laporan Tindakan 
Listia Nur Febrianti, Ida Sugiarti. Kelengkapan Pengisian Formulir Laporan Operasi Kasus Bedah Obgyn ....

Operasi Di Rumah Sakit Pelni Petamburan. [Online]. Tersedia: http://digilib esa unggul. ac.id/public/UEU-NonDegree-4819SONI\%2520HIDAYAT.pdf. [16 Januari 2018]

KARS. (2012). Penilaian Akreditasi Rumah Sakit. Jakarta

Koeswadji, Hermien Hadiati. (1998). Hukum Kedokteran (Studi Hubungan Hukum dalam Mana Dokter sebagai Salah Satu Pihak). Citra Aditya Bakti : Bandung.

Komalawati, Veronica. (2002). Peran Informed Consent dalam Transaksi Terapeutik. Bandung : PT. Citra Aditya Bakti.

Martha, Evi dan Kresno, Sudarti. (2016). Metodologi Penelitian Kuantitatif untuk Bidang Kesehatan. Jakarta : Rajawali Pers.

Notoatmodjo, Soekidjo. (2014). Metodologi Penelitian Kesehatan. Edisi Revisi, Cetakan Kedua. Jakarta: Rineka Cipta.

Paguci, Sutomo. (2013). Kasus dr Ayu CS: Malpraktik atau Kriminal Murni?. [Online]. Tersedia http://www.kompasiana.com/ sutomo-paguci/kasus-dr-ayu-cs-malpraktikatau-kriminal-murni. [4 Maret 2018].
Rahayu NS, Sugiarsi S (2014). Analisis Kuantitatif Dokumen Rekam Medis Pasien Rawat Inappada Kasus Chronic Kidney Disease Triwulan Ivdi Rsud Pandan Arang Boyolali. Jurnal Rekam Medis Vol.7 No.2. Hal 49 -60

Saryono dan Anggraeni, Mekar Dwi. (2010). Metode Penelitian Kualitatif dalam Bidang Kesehatan. Yogyakarta : Nuha Medika.

Subekti, R. (2015). Hukum Pembuktian. Jakarta : Balai Pustaka.

Sudra, Rano Indradi. (2017). Rekam Medis (Edisi 2). Tanggerang Selatan: Universitas Terbuka.

Sugiarti, Ida. (2017). Catatan Kuliah. Tasikmalaya : catatan tidak diterbitkan

Sujarweni, V. Wiratna. (2014). Metodologi Penelitian. Yogyakarta : Pustaka Baru Press.

Sugiyono. (2014). Metode Penelitian Kombinasi (Mixed Methods). Bandung : Alfabeta.

Sugiyono. (2015). Metode Penelitian Kuantitatif, Kualitatif, dan R\&D. Bandung : Alfabeta.

Wahjoepramono, Eka Julianta. (2012). Konsekuensi Hukum dalam Profesi Medik. Bandung : Karya Putra Darwati. 